\title{
PEMBELAJARAN BERBASIS TIK MENGGUNAKAN METODE DISCOVERY LEARNING DENGAN PEER ASSESSMENT DITINJAU DARI GAYA BELAJAR SISWA KELAS VIII SMPN KOTA BANJARMASIN
}

\author{
Asy'ari $^{1} \&$ M. Rizki Zulkarnain ${ }^{2}$
}

1. Pendidikan Teknologi Informasi STKIP PGRI Banjarmasin asyari153@stkipbjm.ac.id (085248587493)

2. Pendidikan Teknologi Informasi STKIP PGRI Banjarmasin m.rizki.z@gmail.com (0816216969)

\begin{abstract}
ABSTRAK
Tujuan penelitian ini adalah untuk mengetahui proses dan hasil pengembangan model pembelajaran berbasis TIK menggunakan metode discovery learning disertai dengan peer assessment serta efektivitas pembelajaran berbasis TIK dengan metode discovery learning disertai peer assessment terhadap hasil belajar siswa ditinjau dari gaya belajar siswa. Penelitian ini terbagi menjadi dua tahap. Tahap pertama adalah tahap pengembangan model pembelajaran yang termasuk ke dalam penelitian pengembangan (research and development). Tahap berikutnya adalah uji efektivitas model yang termasuk ke dalam penelitian eksperimental semu dengan desain penelitian $3 \times 3$. Populasi dari penelitian ini adalah seluruh siswa kelas VIII SMPN Kota Banjarmasin. Sampel dalam penelitian ini berjumlah 265 orang. Teknik analisis data yang digunakan adalah uji ANOVA dua jalan dengan sel tak sama. Berdasarkan uji hipotesis, diperoleh kesimpulan bahwa hasil belajar siswa yang diberi perlakuan model pembelajaran berbasis TIK menggunakan metode discovery learning disertai dengan peer assessment lebih baik dari hasil belajar siswa yang diberi model pembelajaran berbasis TIK menggunakan metode discovery learning dan model pembelajaran konvensional. Selain itu, hasil belajar siswa yang diberi perlakuan model pembelajaran berbasis TIK menggunakan metode discovery learning lebih baik dari hasil belajar siswa yang diberi model pembelajaran konvensional

Kata Kunci: Pembelajaran Berbasis TIK, Discovery Learning, Peer Assessment, Gaya Belajar

\section{PENDAHULUAN}

Dewasa ini Pendidikan memiliki peranan yang sangat penting dalam menghadapi era globalisasi serta kemajuan Ilmu Pengetahuan dan Teknologi (IPTEK). Untuk menghadapi hal tersebut pemerintah Indonesia melakukan penyempurnaan kurikulum yang dinamakan kurikulum 2013. Kurikulum ini bertujuan untuk mempersiapkan manusia Indonesia agar memiliki kemampuan hidup sebagai pribadi dan warga negara yang beriman, produktif, kreatif, inovatif, dan afektif serta mampu berkontribusi pada kehidupan bermasyarakat, berbangsa, bernegara, dan peradaban dunia.
\end{abstract}


Matematika merupakan salah satu mata pelajaran yang tercantum dalam kurikulum dan diberikan pada setiap jenjang pendidikan, mulai dari jenjang pendidikan terendah sampai jenjang pendidikan tertinggi. Salah satu jenjang pendidikan yang mempelajari matematika adalah Sekolah Menengah Pertama (SMP) sederajat. Berdasarkan peraturan Menteri Pendidikan dan Kebudayaan nomor 68 tahun 2013 bahwa beberapa kompetensi dasar yang harus dimiliki siswa Sekolah Menengah Pertama (SMP) sederajat pada mata pelajaran matematika adalah: (1) Menunjukkan sikap logis, kritis, analitik, konsisten dan teliti, bertanggung jawab, responsif, dan tidak mudah menyerah dalam memecahkan masalah; (2) Memiliki rasa ingin tahu, percaya diri, dan ketertarikan pada matematika serta memiliki rasa percaya pada daya dan kegunaan matematika, yang terbentuk melalui pengalaman belajar; (3) Memiliki sikap terbuka, santun, objektif, menghargai pendapat dan karya teman dalam interaksi kelompok maupun aktivitas sehari-hari. Diharapkan dengan tujuan tersebut siswa dapat memahami materi matematika, sehingga kompetensi yang diharapkan dapat tercapai secara maksimal.

Sistem pembelajaran konvensional di sekolah saat ini diyakini kurang efektif, konsep-konsep kemampuan otak, kecerdasan, dan kreativitas telah berkembang dengan pesat seiring dengan kemajuan dalam bidang teknologi dan komunikasi. Perkembangan tersebut memberikan pengaruh terhadap penguatan yang ingin mengoreksi kelemahan dan kekurangan yang ada pada sistem pembelajaran konvensional. Dalam sistem konvensional, proses transfer of knowledge dilakukan dengan menggunakan papan tulis sebagai sarana utama, ruangan dikelola dengan format yang statis dan guru menjadi satu-satunya informan yang expect dalam bidangnya (teacher centered). Di era globalisasi saat ini TIK (Teknologi Informasi dan komunikasi) menjadi kebutuhan yang mendasar dalam menentukan kualitas dan efektivitas proses pembelajaran. Dryden dan Vos (2003) menyimpulkan dari hasil penelitian mereka bahwa dalam sistem pendidikan yang terbukti berhasil, citra diri ternyata lebih penting dari materi pelajaran. Dengan demikian, konsep pendidikan masa depan ialah diarahkan kepada bagaimana membangkitkan gairah siswa untuk belajar secara menyenangkan (how student learn). Salah satu pendekatan dan metode yang dapat digunakan untuk meningkatkan aspek tersebut ialah dengan pemanfaatan Information and Comunication Technology (ICT) dalam proses pembelajaran. Mean dalam (Suryadi, 2007) menerangkan bahwa kebutuhan masyarakat persekolahan untuk memanfaatkan teknologi dalam pembelajaran merupakan bagian dari reformasi pembelajaran. Selain membantu menciptakan kondusi belajar yang kondusif bagi siswa, peran penting dari teknologi informasi dan komunikasi dalam proses pembelajaran adalah menyediakan seperangkat media dan alat (tool) untuk mempermudah dan mempercepat pekerjaan siswa, serta tentu saja memberi keterampilan penggunaan teknologi tinggi (advance skill) (Suryadi, 2007: 92). Selain itu, antara siswa dan sumber-sumber belajar dapat terjadi kapan saja dan di mana saja tidak terbatas oleh ruang dan waktu (space and time), serta proses penyampaian dan penyajian materi pembelajaran maupun gagasan dapat menjadi lebih menarik dan menyenangkan. Dengan demikian, kehadiran dan kemajuan ICT di era komunikasi global saat ini telah memberikan peluang dan perluasan interaksi antara guru dan siswa, interaksi tidak hanya terbatas di ruang kelas saja. Sehingga di rumah siswa 
dapat mengualangi materi dengan baik. Untuk itu, guru dapat memanfaatkan berbagai jenis media secara bersamaan dalam bentuk multimedia pembelajaran. Penggunaan multimedia interaktif yang memuat komponen audio-visual untuk penyampaian materi pembelajaran dapat menarik perhatian siswa untuk belajar, dan juga dapat memberikan kesempatan kepada siswa untuk melakukan eksperimen semu dan ekplorasi sehingga memberikan pengalaman belajar daripada hanya sekedar mendengar uraian guru. Selanjutnya, kehadiran media dalam proses pembelajaran memiliki makna yang sangat urgen, ketidakjelasan materi yang disampaikan dapat dibantu dengan menghadirkan media sebagai perantara. Kerumitan materi yang akan disampaikan kepada anak dapat disederhanakan dengan media. Selain itu, media dapat mewakili apa yang kurang mampu diucapkan seorang guru melalui kata-kata atau kalimat tertentu. Bahkan materi yang abstrak dapat dikonkretkan melalui media.

Dalam kegiatan pembelajaran guru merupakan komponen proses yang utama dalam penyelenggaraan pendidikan. Seperti yang ditulis Looney (2009: 6) bahwa guru sebaiknya mengambil peran yang berbeda, yaitu tidak hanya mengajar "di depan kelas" tetapi supaya siswa terlibat aktif dalam proses pembelajaran, siswa melakukan penyelidikan atau penemuan mereka sendiri dan mengembangkan solusi. Kemudian guru dan siswa dapat menyesuaikan program dengan kebutuhan pembelajaran dan minat siswa secara individu. Balim (2009: 2) juga berpendapat bahwa salah satu metode yang sesuai dengan pendekatan konstruktivisme adalah pembelajaran discovery seperti yang dituliskan dalam jurnalnya sebagai berikut :

Today, it is believed that methods in accordance with the constructivist approach in which the students learn more effectively by constructing their own knowledge, should be used. One of these methods is discovery learning.

(Saat ini, diyakini bahwa metode yang sesuai dengan pendekatan konstruktivis dimana siswa belajar lebih efektif dengan membangun pengetahuan mereka sendiri, harus digunakan. Salah satu metode ini adalah pembelajaran discovery).

Lebih lanjut Balim (2009:16) dalam hasil penelitian menyimpulkan bahwa "Dengan menggunakan metode pembelajaran discovery, yang merupakan salah satu dari berbagai metode pengajaran dimana siswa aktif dan guru membimbing mereka dapat meningkatkan hasil belajar dan keterampilan belajar siswa". Selanjutnya hasil penelitian yang dilakukan oleh Meyer dalam Jamilah (2013: 4) menunjukkan bahwa proses penemuan (discovery) dalam pembelajaran akan membantu siswa untuk memahami dan menganalisis proses kreativitas dan pengambilan keputusan dari temuannya. Dari pendapat-pendapat tersebut supaya siswa terlibat aktif dalam pembelajaran dan membangun pengetahuannya sendiri maka diterapkan metode penemuan (discovery) dalam pembelajaran, guru mengajak agar siswa benar-benar aktif dalam pembelajaran dengan membimbing siswa dalam menemukan sendiri konsep dari materi yang dipelajarinya, sehingga pembelajaran menjadi lebih bermakna dan memungkinkan siswa untuk menguasai tujuan pembelajarannya. Hal ini kemungkinan besar dapat menyebabkan prestasi belajar siswa lebih meningkat.

Pada kesempatan yang lain, proses penilaian juga layak menjadi sorotan ketika terjadi ketimpangan dalam dunia pendidikan. Apabila dicermati sebenarnya praktik penilaian yang dilakukan secara tepat akan menghasilkan hasil belajar yang 
meningkat, yakni penilaian yang melibatkan siswa. Seperti yang diungkapkan oleh Nick (2010) bahwa "in the context of student assessment, innovation aims to produce students who are deep rather than surface learners, highly motivated, equipped with a range of transferable skills, active and reactive participants in the learning process". Penilaian memiliki pengaruh penting pada satu strategi, motivasi, dan hasil belajar siswa. Oleh sebab itu, diperlukan paradigma baru dalam penilaian supaya penilaian merupakan suatu kegiatan yang termasuk dalam proses pembelajaran sedemikian sehingga kegiatan penilaian dapat membantu dalam meningkatkan kualitas pembelajaran. Salah satu tujuan utama penilaian ialah untuk memberikan umpan balik kepada siswa. Penegasan lebih lanjut terdapat dalam lampiran Peraturan Menteri Pendidikan Nasional Nomor 20 Tahun 2007 tanggal 11 Juni 2007 tentang Standar Penilaian Pendidikan pada poin E penilaian oleh pendidik, butir keenam menjelaskan mengenai kegiatan mengembalikan hasil pemeriksaan pekerjaan siswa disertai balikan/komentar yang mendidik serta pada butir ketujuh yang intinya memanfaatkan hasil penilaian untuk perbaikan pembelajaran. Peer assessment merupakan cara penilaian hasil belajar yang berpusat pada siswa dan dapat dilakukan untuk penilaian formatif. Metode penilaian peer assessment dapat diterapkan untuk menilai kemampuan kognitif maupun kemampuan non kognitif siswa. Penggunaan metode penilaian peer assessment ditujukan untuk memperoleh feedback bagi peserta didik sehingga dapat meningkatkan proses dan hasil belajar siswa sehingga tujuan pembelajaran dapat tercapai dengan optimal.

Hal lain yang perlu diperhatikan agar siswa berhasil dalam belajar metematika adalah karakteristik dan kondisi siswa. Karakteristik siswa yang dimaksud disini antara lain: kemampuan awal, motivasi dan gaya belajar. Gaya belajar dari seorang siswa juga perlu diperhatikan. Seorang guru yang baik tentu tidak akan langsung memvonis siswa yang nilainya jelek adalah siswa yang tidak bisa. Guru harus mencari informasi kenapa siswa yang bersangkutan mendapat nilai yang jelek. Terkait dengan hal tersebut, informasi penting yng perlu diketahui guru antara lain terkait dengan gaya belajar siswa.

Melalui permasalahan yang muncul, maka dalam penelitian ini yang menjadi pokok permasalahan, yaitu berkaitan dengan inovasi model pembelajaran, paradigma tentang penilaian dan pemilihan model pembelajaran. Oleh karena itu peneliti tertarik untuk melaksanakan penelitian pengembangan, yaitu pengembangan model pembelajaran berbasis TIK menggunakan metode discovery learning dengan peer assessment pada pembelajaran matematika ditinjau dari gaya belajar siswa kelas VIII SMP Negeri di Kota Banjarmas in Tahun Ajaran 2017/2018.

\section{METODE PENELITIAN}

Jenis penelitian yang digunakan adalah penelitian dan pengembangan sedangkan prosedur penelitian mengacu kepada prosedur $\mathrm{R}$ dan $\mathrm{D}$ yang dikemukakan oleh Borg dan Gall dengan beberapa modifikasi. Berikut akan diuraikan langkahlangkah penelitian yang dilakukan: (1) Pengembangan model pembelajaran berbasis TIK menggunakan metode discovery learning dengan peer assessment. Pengembangan model dalam penelitian ini dimaksudkan untuk mendapatkan suatu pengembangan model pembelajaran berbasis TIK menggunakan metode discovery 
learning dengan peer assessment yang dapat dipraktikkan secara nyata dalam proses belajar mengajar. Adapun tahapan dalam pengembangan model terdiri dari tujuh tahap, yaitu : (a) Studi literatur; (b) Perencanaan pengembangan model pembelajaran berbasis TIK menggunakan metode discovery learning dengan peer assessment; (c) Focus Group Discussion (FGD); (d) Pembuatan prototipe model; (e) Validasi model, (f) Uji coba model; (g) Penetapan model. (2) Uji efektivitas model. Pada uji efektivitas model, dilakukan komparasi hasil belajar siswa yang dikenai pengembangan model pembelajaran berbasis TIK menggunakan metode discovery learning dengan peer assessment dengan siswa yang tidak dikenai model tersebut. Uji efektivitas model ini adalah penelitian eksperimental semu (quasi-experimental research). Pada uji efektivitas ini dilakukan sebanyak enam kali pembelajaran, dan satu kali untuk ujian. Manipulasi variabel dalam penelitian ini dilakukan pada variabel bebas yaitu pengembangan model pembelajaran berbasis TIK menggunakan metode discovery learning dengan peer assessment yang dikenakan terhadap kelas eksperimen pertama, pengembangan model pembelajaran berbasis TIK menggunakan metode discovery learning yang dikenakan terhadap kelas eksperimen kedua, dan model pembelajaran konvensional dikenakan terhadap kelas kontrol. Variabel lain yang ikut mempengaruhi veriabel terikat adalah gaya belajar dari masing-masing siswa. Dalam tahap uji efektivitas ini, sekolah yang dipilih berbeda dengan sekolah yang dipakai ketika uji coba model pembelajaran. Selanjutnya untuk keperluan uji efektivitas model, dalam penelitian ini akan menggunakan penelitian eksperimental semu dengan desain fakatorial $3 \times 3$. Populasinya adalah seluruh siswa kelas VIII SMPN se-Kota Banjarmasin tahun pelajaran 2017/2018. Sampel dalam penelitian ini dipilih dengan teknik stratified cluster random sampling. SMP Negeri se-Kota Banjarmasin dikelompokkan ke dalam tiga kelompok (berdasarkan rerata nilai hasil UN siswa di sekolah), yaitu kelompok atas, sedang, dan bawah. Dari masing-masing kelompok kemudian dipilih satu sekolah secara acak. Sampel yang terpilih adalah SMPN 24 Banjarmasin (mewakili kelompok atas), SMPN 14 Banjarmasin (mewakili kelompok sedang) dan SMPN 17 Banjarmasin (mewakili kelompok bawah). Dari masing-masing sekolah dipilih lagi tiga kelas secara acak dan akan diberikan perlakuan yang berbeda, yaitu model pembelajaran berbasis TIK menggunakan metode discovery learning dengan peer assessment, pembelajaran berbasis TIK menggunakan metode discovery learning, dan pembelajaran konvensional. Pada SMPN 24 Banjarmasin, kelas yang terpilih adalah kelas 8G, 8F, dan 8E. Pada SMPN 14 Banjarmasin, kelas yang terpilih adalah kelas 8E, 8D, dan 8F. Pada SMPN 17 Banjarmasin, kelas yang terpilih adalah kelas 8D, 8B, dan 8C. Sampel dalam penelitian ini berjumlah 265 siswa yang terdiri dari 88 siswa pada kelas eksperimen satu, 89 siswa pada kelas eksperimen dua dan 88 siswa pada kelas kontrol. Dalam penelitian ini terdapat dua variabel bebas yaitu model pembelajaran dan gaya belajar siswa dan satu variabel terikat yaitu hasil belajar matematika.

Teknik pengumpulan data menggunakan metode dokumentasi, angket, dan tes. Metode dokumentasi digunakan untuk mengumpulkan data kemampuan awal siswa, metode tes digunakan untuk mengumpulkan data hasil belajar, dan angket gaya belajar siswsa digunakan untuk mengumpulkan data gaya belajar siswa. Instrumen yang digunakan dalam penelitian ini berupa tes objektif bentuk pilihan ganda pada 
materi bangun ruang (kubus dan balok) dan angket gaya belajar siswa (untuk membedakan gaya belajar siswa dalam kategori visual, auditorial atau kinestetik). Tes hasil belajar yang digunakan berupa tes objektif berbentuk pilihan ganda dengan empat alternatif jawaban dengan satu jawaban benar yang terdiri dari 20 soal.

Uji coba instrumen dilakukan di SMPN 23 Banjarmasin. Uji coba dilakukan untuk mengetahui apakah instrumen tes yang telah dibuat telah memenuhi syaratsyarat instrumen yang baik, yaitu validitas isi, daya beda, tingkat kesukaran dan reliabel. Untuk instrumen tes hasil belajar, mengacu pada kriteria yaitu validitas isi, daya pembeda $(\mathrm{D} \geq 0,3)$, tingkat kesukaran $(0,3 \leq \mathrm{P} \leq 0,7)$, dan reliabilitas $\left(\mathrm{r}_{11} \geq\right.$ $0,7)$, dari 30 butir soal yang diujicobakan diperoleh 20 butir soal yang digunakan sebagai alat pengambil data hasil belajar matematika siswa. Uji prasyarat analisis yaitu uji normalitas dengan Lilliefors dan uji homogenitas dengan uji Bartlett. Uji analisis data yang digunakan yaitu analisis variansi dua jalan dengan sel tak sama.

\section{HASIL DAN PEMBAHASAN}

Hasil uji keseimbangan terhadap data kemampuan awal siswa diperoleh bahwa ketiga populasi mempunyai kemampuan awal yang sama. Data kemampuan awal siswa yaitu nilai ulangan akhir semester matematika kelas VIII semester gasal tahun pelajaran 2017/2018 yang diambil sebelum dilakukan penelitian baik pada kelompok eksperimen 1, pada kelompok eksperimen 2, maupun pada kelompok kontrol. Setelah eksperimen, didapatkan data hasil belajar matematika. Adapun rerata hasil belajar matematika kelompok eksperimen dan kelompok kontrol dapat dilihat pada Tabel 1 berikut.

\section{Tabel 1. Rerata Masing-masing Sel dari Data Model Pembelajaran dan Gaya} Belajar.

\begin{tabular}{|c|c|c|c|c|}
\hline \multirow{3}{*}{$\begin{array}{l}\text { Pembelajaran (a) } \\
\text { Berbasis TIK } \\
\text { Discovery Learning } \\
\text { peer assessment }\left(a_{1}\right)\end{array}$} & \multicolumn{3}{|c|}{$\begin{array}{c}\text { Gaya Belajar Siswa } \\
\text { Siswa }(b)\end{array}$} & \multirow[t]{2}{*}{$\begin{array}{l}\text { Rerata } \\
\text { Marginal }\end{array}$} \\
\hline & $\begin{array}{c}\text { Visual } \\
\left(b_{i}\right)\end{array}$ & $\begin{array}{c}\text { Auditorial } \\
\left(b_{2}\right)\end{array}$ & $\begin{array}{c}\text { Kinestetik } \\
\left(b_{b}\right)\end{array}$ & \\
\hline & 76,97 & 77,50 & 69,57 & 75,23 \\
\hline Berbasis TIK $\left(a_{z}\right)$ & 72,27 & 70,47 & 63,75 & 69,33 \\
\hline Konvensional $\left(a_{3}\right)$ & 66,06 & 64,84 & 58,91 & 63,75 \\
\hline Rerata Marginal & 71,77 & 70,94 & 64,08 & \\
\hline
\end{tabular}

Sebelum dilakukan analisis variansi dua jalan, terlebih dahulu dilakukan uji normalitas dan uji homogenitas sebagai uji prasyarat analisis variansi. Selanjutnya dilakukan uji analisis variansi dua jalan dengan sel tak sama. Rangkuman uji analisis variansi disajikan pada Tabel 2 . 
Tabel 2. Rangkuman Analisis Variansi Dua Jalan

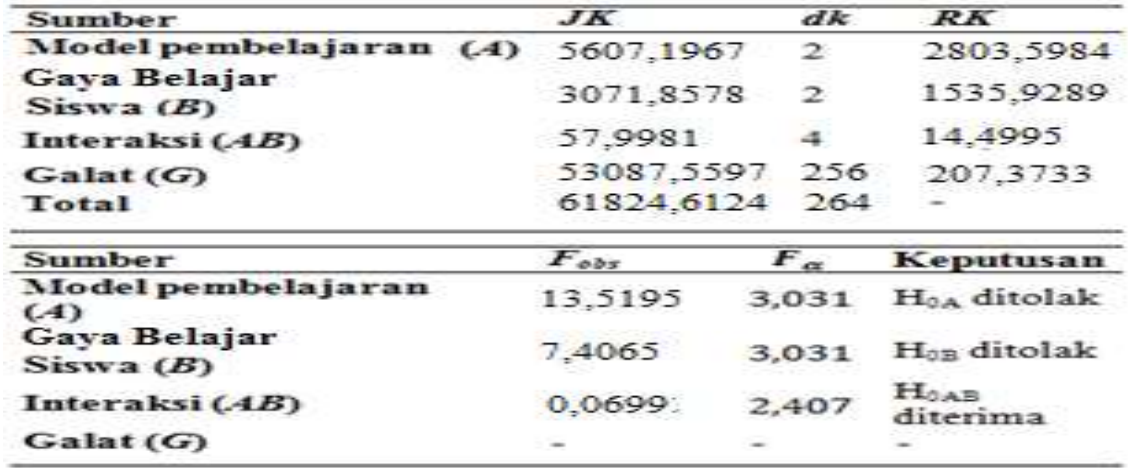

Kesimpulan analisis variansi dua jalan dengan sel tak sama berdasarkan Tabel 2. adalah (1) Pada efek utama antar baris (A), siswa-siswa yang dikenai dengan model pembelajaran berbasis TIK menggunakan metode discovery learning dengan peer assessment, pembelajaran berbasis TIK menggunakan metode discovery learning, dan konvensional memberikan efek yang berbeda terhadap hasil belajar matematika siswa. (2) Pada efek utama antar kolom (B), Gaya belajar visual, auditorial, dan kinestetik memberikan efek yang berbeda terhadap hasil belajar matematika. (3) Pada efek interaksi (AB), tidak terdapat interaksi antara model pembelajaran dan gaya belajar siswa terhadap hasil belajar matematika siswa.

Berdasarkan anava dua jalan diperoleh bahwa $\mathrm{H}_{0 \mathrm{~A}}$ ditolak, sehingga perlu dilakukan uji lanjut pasca analisis variansi dengan metode Scheffe' untuk uji komparasi antar baris. Rangkuman perhitungan uji lanjut rerata antar baris disajikan pada Tabel 3.

Tabel 3. Rangkuman Hasil Uji Komparasi Ganda Antar Baris

\begin{tabular}{|c|c|c|c|}
\hline $\mathrm{H}_{0}$ & Fols & Frabel & Keputusan $\mathrm{Uji}$ \\
\hline$\mu_{2 .}=\mu_{2}$. & 7,4312 & 6,062 & $\mathrm{H}_{0}$ ditolak \\
\hline$\mu_{2}=\mu_{3}$. & 27,949 & 6,062 & $\mathbf{H}_{0}$ ditolak \\
\hline$\mu_{2}=\mu_{3}$. & 6,6338 & 6,062 & $\mathrm{H}_{0}$ ditolak \\
\hline
\end{tabular}

Berdasarkan hasil analisis variansi dua jalan dengan sel tak sama untuk efek utama faktor $\mathrm{A}$ (model pembelajaran) diperoleh harga statistik uji $\mathrm{F}_{\mathrm{a}}=13,5195$ dan $F_{(0,05,2,256)}=3,031$, ternyata $F_{a}>F_{(0,05,2,256)}$, sehingga $F_{a} \in D K$ dengan demikian $H_{0 A}$ ditolak. Karena $\mathrm{H}_{0 \mathrm{~A}}$ ditolak maka perlu dilakukan uji lanjut anava yaitu uji komparasi ganda. Berdasarkan Tabel 3 hasil uji komparasi antar baris pada masing-masing kategori model pembelajaran dan Tabel 1, diperoleh simpulan bahwa hasil belajar siswa yang diberi perlakuan model pembelajaran berbasis TIK menggunakan metode discovery learning dengan peer assessment lebih baik dari hasil belajar siswa yang diberi model pembelajaran berbasis TIK menggunakan metode discovery learning dan model pembelajaran konvensional. Selain itu, hasil belajar siswa yang diberi perlakuan model pembelajaran berbasis TIK menggunakan metode discovery learning lebih baik dari hasil belajar siswa yang diberi model pembelajaran konvensional. Hal ini dimungkinkan karena model pembelajaran berbasis TIK menggunakan metode discovery learning dengan peer assessment merupakan model 
pembelajaran yang mendorong siswa untuk aktif dalam pembelajaran. Dalam model pembelajaran berbasis TIK menggunakan metode discovery learning dengan peer assessment siswa dituntut untuk aktif dalam belajar materi bangun ruang dengan pembelajaran berbasis komputer yang inovatif. Selain itu ditambah lagi dengan adanya penilaian teman sejawat siswa (peer assessment) yang digunakan untuk mendapatkan partisipasi siswa melalui tulisan untuk dapat lebih mengoptimalkan kemampuan berpikir siswa dalam hal menilai teman sejawatnya secara tertulis. Sedangkan pada model pembelajaran konvensional guru lebih mendominasi pembelajaran sehingga siswa kurang aktif dalam memperoleh informasi yang disampaikan. Selain itu ada kecendrungan siswa acuh untuk bertanya pada gurunya apabila ada materi yang belum mereka pahami dan pembelajaran cenderung monoton sehingga siswa merasa jenuh dalam belajar. Menurut Muhibbin Syah (2008:165) seseorang siswa yang sedang dalam kejenuhan sistem akalnya tidak dapat bekerja sebagaimana yang diharapkan dalam memproses item-item informasi sehingga prestasi belajar dapat menurun. Sehingga dapat disimpulkan bahwa siswa yang diberi model pembelajaran berbasis TIK menggunakan metode discovery learning dengan peer assessment mempunyai hasil belajar matematika yang lebih baik dari siswa yang diberi model pembelajaran konvensional.

Berdasarkan anava dua jalan diperoleh bahwa $\mathrm{H}_{0 \mathrm{~B}}$ ditolak, sehingga perlu dilakukan uji lanjut pasca analisis variansi dengan metode Scheffe' untuk uji komparasi antar kolom. Rangkuman perhitungan uji lanjut rerata antar kolom disajikan pada Tabel 4.

Tabel 4. Rangkuman Hasil Uji Komparasi Ganda Antar Kolom

\begin{tabular}{cccc}
$\mathrm{H}_{0}$ & $\mathrm{~F}_{\text {obs }}$ & $\mathrm{F}_{\text {tabel }}$ & Keputusan Uji \\
\hline$\mu_{2}=\mu_{2}$ & 0,1619 & 6,062 & $\mathrm{H}_{0}$ diterima \\
$\mu_{L_{1}}=\mu_{3}$ & 11,713 & 6,062 & $\mathrm{H}_{0}$ ditolak \\
$\mu_{2}=\mu_{3}$ & 9,2029 & 6,062 & $\mathrm{H}_{0}$ ditolak \\
\hline
\end{tabular}

Berdasarkan hasil analisis variansi dua jalan dengan sel tak sama untuk efek utama faktor $\mathrm{B}$ (Gaya belajar siswa) diperoleh harga statistik uji $\mathrm{F}_{\mathrm{b}}=7,4065$ dan

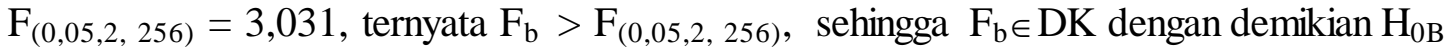
ditolak. Karena $\mathrm{H}_{0 \mathrm{~B}}$ ditolak maka perlu dilakukan uji lanjut anava yaitu uji komparasi ganda. Berdasarkan Tabel 4 hasil uji komparasi antar kolom pada masing-masing kategori gaya belajar siswa, diperoleh bahwa $\mathrm{H}_{0}$ untuk $\mu_{1}=\mu_{2}$ diterima dan $\mathrm{H}_{0}$ untuk $\mu_{1}=\mu_{3}$ dan $\mu_{2}=\mu_{3}$ ditolak. Hal ini berarti pada tingkat signifikansi $\alpha=0,05$ Siswa dengan gaya belajar visual secara signifikan memiliki hasil belajar yang sama dengan siswa yang memiliki gaya belajar auditorial, siswa yang memiliki gaya belajar visual dan auditorial secara signifikan memiliki hasil belajar matematika yang berbeda dengan siswa yang memiliki gaya belajar kinestetik. Berdasarkan hasil rataan marginal dapat dilihat pada Tabel 1, diperoleh rerata hasil belajar matematika siswa yang memiliki gaya belajar visual 71,77 , rerata hasil belajar siswa yang memiliki gaya belajar auditorial adalah 70,94 sedangkan rerata hasil belajar siswa yang memiliki gaya belajar kinestetik sebesar 64,08. 
Berdasarkan Tabel 4 hasil uji komparasi antar kolom pada masing-masing kategori gaya belajar dan rerata masing-masing sel kategori gaya belajar siswa pada Tabel 1, diperoleh simpulan bahwa siswa dengan gaya belajar visual mempunyai hasil belajar yang sama baiknya dengan siswa yang memiliki gaya belajar auditorial, siswa dengan gaya belajar visual mempunyai hasil belajar lebih baik dibandingkan siswa yang memiliki gaya belajar kinestetik, dan siswa dengan gaya belajar auditorial mempunyai hasil belajar lebih baik dibandingkan siswa yang memiliki gaya belajar kinestetik. Hasil penelitian ini tidak sesuai dengan hipotesis awal yang menyatakan bahwa siswa dengan gaya belajar auditorial mempunyai hasil belajar yang lebih baik dibanding siswa dengan gaya belajar visual. Ketidaksesuaian ini kemungkinan disebabkan oleh keterbatasan penelitian ini yang tidak mampu mengontrol variabelvariabel lain di luar gaya belajar siswa. Secara teori, hasil penelitian ini sama dengan hasil penelitian yang dilakukan oleh Nur Janah (2009) yang menyatakan tidak ada perbedaan hasil belajar yang signifikan antara siswa dengan gaya belajar visual dan auditorial.

Berdasarkan hasil perhitungan analisis variansi dua jalan sel tak sama pada efek interaksi $\mathrm{AB}$ (model pembelajaran dan kategori gaya belajar siswa) diperoleh $\mathrm{F}_{\mathrm{AB}}=0,0699$ dan $D K=\{F \mid F>2,407\}$, ini berarti $F_{A B} \notin D K$. Sehingga $\mathrm{H}_{0 \mathrm{AB}}$ diterima, sehingga tidak ada interaksi antara model pembelajaran dan kategori gaya belajar terhadap hasil belajar siswa, sehingga tidak perlu dilakukan komparasi ganda antar sel. Artinya kesimpulan pada efek khusus (pada masing-masing model pembelajaran dan pada masing-masing gaya belajar) akan sejalan dengan kesimpulan pada efek utama yaitu (1) Pada kategori gaya belajar visual, auditorial maupun kinestetik, antara model pembelajaran berbasis TIK menggunakan metode discovery learning dengan peer assessment memberikan hasil belajar lebih baik daripada model pembelajaran berbasis TIK menggunakan metode discovery learning dan model pembelajaran konvensional. Pada kategori gaya belajar visual, auditorial maupun kinestetik, model pembelajaran berbasis TIK dengan metode discovery memberikan hasil belajar lebih baik daripada model pembelajaran konvensional. (2) Pada model pembelajaran berbasis TIK menggunakan metode discovery learning dengan peer assessment, pembelajaran berbasis TIK menggunakan metode discovery learning maupun model pembelajaran konvensional, siswa dengan gaya belajar visual mempunyai hasil belajar yang sama baiknya dengan siswa yang memiliki gaya belajar auditorial, siswa dengan gaya belajar visual mempunyai hasil belajar lebih baik dibandingkan siswa yang memiliki gaya belajar kinestetik, dan siswa dengan gaya belajar auditorial mempunyai hasil belajar lebih baik dibandingkan siswa yang memiliki gaya belajar kinestetik.

\section{SIMPULAN DAN SARAN}

\section{A. Simpulan}

Berdasarkan hasil penelitian pengembangan, maka dapat disimpulkan syntax untuk model pembelajaran berbasis TIK menggunakan metode discovery learning dengan peer assessment (penilaian teman sejawat) adalah sebagai berikut. 1) Pendahuluan, pada tahap ini guru menyampaikan tujuan pembelajaran dan motivasi kepada siswa. 2) Eksplorasi, Guru menjelaskan materi pelajaran tentang bangun 
ruang sisi datar dengan menggunakan media pembelajaran berbantuan komputer yang diproyeksikan menggunakan LCD. Pada tahap ini guru memberikan stimulus bisa berupa pertanyaan-pertanyaan yang merangsang keingintahuan siswa maupun masalah yang berkaitan dengan materi yang disajikan dalam LKS. Pada langkah ini guru membimbing siswa untuk menemukan konsep dari materi yang dipelajari dengan menggunakan LKS dengan metode discovery, LKS ini mengajak siswa untuk mengkonstruksi sendiri pengetahuannnya agar siswa dapat menemukan konsep dari materi yang dipelajari. Dalam LKS, siswa diarahkan untuk menjawab pertanyaanpertanyaan yang membimbing atau mengarahkan siswa untuk menemukan konsep dari materi yang sedang dipelajari. Misalnya siswa akan menemukan apa yang dimaksud dengan diagonal bidang, diagonal ruang, bidang diagonal, dan lain sebagainya yang terkait dengan materi bangun ruang sisi datar. Pada tahapan ini guru hanya berperan sebagai fasilitator. 3) Guru memberikan soal esensial yang bisa dikerjakan dalam waktu sekitar 10-15 menit, dan menyuruh siswa untuk memikirkan dan mengerjakan secara mandiri. 4) Setelah siswa mengerjakan soal, guru memintanya untuk berpasangan. Pada proses ini guru akan membagikan rubrik atau pedoman penilaian yang akan digunakan siswa untuk melakukan peer assessment (penilaian sejawat). Ketika proses peer assessment (penilaian sejawat) dilakukan, guru tetap memberikan bimbingan jika ada siswa yang belum paham. 5) Setelah proses penilaian sejawat selesai, beberapa pasangan mempresentasikan hasil pengetahuan yang didapat pada proses penilaian sejawat. 6) Penutup, pada tahap ini hasil peer assessment (penilaian sejawat) dikembalikan kepada pemiliknya untuk dijadikan koreksi bersama dan selanjutnya dikumpulkan kepada guru untuk diperiksa ulang dan diberi umpan balik, yang kemudian dikembalikan lagi kepada siswa pada pertemuan berikutnya. Pada tahap ini guru juga bisa memberikan pekerjaan rumah sebagai latihan soal untuk belajar siswa di rumah.

Berdasarkan hasil penelitian eksperimental semu dapat disimpulkan sebagai berikut. 1) Hasil belajar siswa yang diberi perlakuan model pembelajaran berbasis TIK menggunakan metode discovery learning dengan peer assessment lebih baik dari hasil belajar siswa yang diberi perlakuan model pembelajaran berbasis TIK menggunakan metode discovery learning dan model pembelajaran konvensional, dan hasil belajar siswa yang diberi perlakuan model pembelajaran berbasis TIK menggunakan metode discovery learning lebih baik dari hasil belajar siswa yang diberi perlakuan dengan menggunakan model pembelajaran konvensional, 2) Hasil belajar siswa dengan gaya belajar visual mempunyai hasil belajar yang sama baiknya dengan siswa yang memiliki gaya belajar auditorial, siswa dengan gaya belajar visual mempunyai hasil belajar lebih baik dibandingkan siswa yang memiliki gaya belajar kinestetik, dan siswa dengan gaya belajar auditorial mempunyai hasil belajar lebih baik dibandingkan siswa yang memiliki gaya belajar kinestetik, 3) Pada model pembelajaran berbasis TIK menggunakan metode discovery learning dengan peer assessment, pembelajaran berbasis TIK menggunakan metode discovery learning maupun model pembelajaran konvensional. Siswa dengan gaya belajar visual mempunyai hasil belajar yang sama baiknya dengan siswa yang memiliki gaya belajar auditorial, siswa dengan gaya belajar visual mempunyai hasil belajar lebih baik dibandingkan siswa yang memiliki gaya belajar kinestetik, dan siswa dengan 
gaya belajar auditorial mempunyai hasil belajar lebih baik dibandingkan siswa yang memiliki gaya belajar kinestetik, 4 4) Pada kategori gaya belajar visual, auditorial maupun kinestetik, antara model pembelajaran berbasis TIK menggunakan metode discovery learning dengan peer assessment memberikan hasil belajar lebih baik daripada model pembelajaran berbasis TIK menggunakan metode discovery learning dan model pembelajaran konvensional. Pada kategori gaya belajar visual, auditorial maupun kinestetik, model pembelajaran berbasis TIK dengan metode discovery learning memberikan hasil belajar lebih baik daripada model pembelajaran konvensional.

\section{B. Saran}

Berdasarkan simpulan, adapun saran dari hasil penelitian ini adalah bagi pendidik hendaknya model pembelajaran berbasis TIK menggunakan metode discovery learning dengan peer assessment ataupun model pembelajaran berbasis TIK dapat dijadikan sebagai salah satu referensi dalam pembelajaran matematika di kelas, karena berdasarkan hasil penelitian kedua model tersebut memberikan hasil belajar yang lebih baik dibandingkan model pembelajaran konvensional. Selain itu, guru hendaknya memperhatikan faktor lain dari dalam diri siswa yaitu gaya belajar siswa, karena dalam penelitian ini gaya belajaar siswa memberikan pengaruh terhadap hasil belajar.

\section{DAFTAR RUJUKAN}

Balım, A. G. (2009). "The Effects of Discovery Learning on Students' Success and Inquiry Learning Skills". Egitim Arastirmalari Eurasian Journal of Educational Research, 35: 1-20.

Dryden, G \& Vos, J. (2003). Revolusi Cara Belajar (The Learning Revolution). Bandung: Kaifa.

Looney, J. W. (2009). "Assessment and Innovation in Education", OECD Education Working Papers, 24(3): 5-8

Lu, J \& Law, N. (2011). Online Peer Assessment: Effects of Cognitive and Affective Feedback. Faculty of Education, The University of Hongkong. No.40: 257275.

Muhibbin Syah. (2008). Psikologi Pendidikan dengan pendekatan Baru. Bandung : Remaja Rosdakarya.

Nick, Z. Z. (2010). Innovative Assessment For Learning Enhancement : Issue And Practices. Technological Education, Institute of Piraeus. Vol. 3, No. 1

Nur Janah. (2009). Metode Pembelajaran Concept Attainment dalam Meningkatkan Prestasi Belajar Matematika Ditinjau dari Gaya Belajar Siswa. Tesis. Tidak Diterbitkan. Universitas Sebelas Maret.

Suryadi, Ace. (2007). Pemanfaatan ICT dalam Pembelajaran. Jurnal Pendidikan Terbuka dan Jarak Jauh. Volume 8, Nomor 1, Maret 2007,83-98. 